\section{Intersections}

Canadian Journal of Music

Revue canadienne de musique
Intersections CANADIAN JOURAL OR MUSIC

\title{
The Eventual Premiere of Issipile: Porpora and the Palchetti War
}

\section{Kurt Markstrom}

Volume 33, numéro 2, 2013

Musical Perspectives, People, and Places: Essays in Honour of Carl Morey

URI : https://id.erudit.org/iderudit/1032695ar

DOI : https://doi.org/10.7202/1032695ar

Aller au sommaire du numéro

Éditeur(s)

Canadian University Music Society / Société de musique des universités canadiennes

ISSN

1911-0146 (imprimé)

1918-512X (numérique)

Découvrir la revue

Citer cet article

Markstrom, K. (2013). The Eventual Premiere of Issipile: Porpora and the Palchetti War. Intersections, 33(2), 53-69. https://doi.org/10.7202/1032695ar
Résumé de l'article

« Là où est impliqué Porpora, le malheur suit. Méfiez-vous, en vérité, d’avoir affaire avec lui ». Les accusations accablantes que porte Métastase à l'endroit de Nicola Porpora dans une lettre incluse dans son Opere (le passage ayant été omis par Charles Burney dans sa traduction anglaise) peuvent être mises en lien avec la "Guerre des loges" se déroulant à Rome en 1732-33 et un procès contre l'imprésario Francesco Cavanna du Teatro della Dame. La cause avait été présentée par un groupe de musiciens, sans doute mené par Porpara, suite à l'annulation, au printemps 1732, de la première de l'opéra de ce dernier, Issipile. Cette annulation était due à la fermeture des théâtres par le pape en raison du conflit entre les ambassadeurs de France et d'Autriche au sujet de leur loge à l'Opéra. En effet, dans cette polémique, Métastase prit le parti de l'imprésario, au dépend du compositeur, parce qu'elle avait entraîné la faillite de Cavanna et la fermeture du Treatro della Dame. Bien qu'une entente ait été conclue pour que la première de l'Issipile de Porpora ait lieu l'année suivante dans un théâtre différent, le Teatro Pioli - qui avait transformé ses loges en un grand balcon - le Teatro della Dame, lui, a gardé ses cinq niveaux de loges et est demeuré fermé jusqu'en 1738. Cette décision du Teatro della Dame peut être considérée comme une stratégie délibérée face à la controverse de la "Guerre des loges".
Copyright ( C Canadian University Music Society / Société de musique des universités canadiennes, 2013
Ce document est protégé par la loi sur le droit d'auteur. L'utilisation des services d'Érudit (y compris la reproduction) est assujettie à sa politique d'utilisation que vous pouvez consulter en ligne.

https://apropos.erudit.org/fr/usagers/politique-dutilisation/ 


\title{
THE EVENTUAL PREMIERE OF ISSIPILE: PORPORA AND THE PALCHETTI WAR
}

\author{
Kurt Markstrom
}

In a letter written in Vienna, 21 June 1732, Metastasio reacted with severe and rather uncharacteristic anger upon hearing news from his friend and confidant, the soprano Marianna Benti Bulgarelli in Rome:

On another matter, can one imagine a greater desolation than that which you have so vividly described in the letter of this morning? In sum, where Porpora is involved, misfortune is bound to ensue. Beware, I beg you, to have as little to do with him as is possible. It is a great thing that an entire city should have to suffer pain for the caprice of an individual; and for motives so frivolous, he has no repugnance to hurt so many and to displease everybody. I feel sorry for those who suffer the loss, because, even without these motives, I feel repugnance at being indifferent. ${ }^{1}$

It is not known what Porpora actually did to make an entire city "suffer pain." Perhaps Metastasio is exaggerating. ${ }^{2}$ His previous letter to Bulgarelli, or "La Romanina" as she was known, dated 14 June, appears to provide more information on what happened: "You could not imagine how much the disgrace of the Teatro delle Dame displeases me. The worst thing is that regardless of the remedy, the loss must be very great for poor Cavanna." ${ }^{3}$

1 "E si può in altro genere immaginare maggiore desolazione di quella che voi vivamente mi rappresentate nella lettera di questa mattina? In somma, dove si mischia Porpora entra per necessità la disgrazia. Guardatevi per carità di non aver mai il minimo affare in sua compagnia. E però una gran cosa, che una città intera abbia a soffrir la pena de' capricci di un solo: e che per motivi così leggieri non si abbia repugnanza di nuocere a tanti, e dispiacere a tutti. Compatisco quei che risentono il danno, perché, senza questo motivo, sento la mia repugnanza ad essere indifferente" (Metastasio [1732] 1953, 3:67-68; all translations by the author, unless stated otherwise).

2 Burney left out all reference to Porpora in his English translation, making the passage even more obscure, fusing into Metastasio's description of the emperor's hunting accident: "And of another kind, can greater desolation be represented to the mind, than that which you have so well described in your letter which I received this morning? It is terrible, that a great city should be obliged to suffer for the caprice of an individual, and that, for such frivolous motives, he should have no repugnance to injuring numbers, and displeasing all. I pity those who feel the loss; and even without this motive, it is impossible to be indifferent" (Burney 1796, 1:90).

3 "Non potete immaginarvi quanto mi dispiaccia la disgrazia del Teatro delle Dame. Il peggio è che, qualunque sia il rimedio, sempre sarà grande il danno del povero Cavanna" (Metastasio [1732] 1953, 3:66). Although Porpora is not mentioned in the letter of 14 June and the delle Dame is not mentioned in the letter of 21 June, the two are obviously connected, in the same way as the description of the hunting accident at the imperial court in the letter of 14 June is referred immediately after the Porpora critique in the letter of 21 June; moreover, we know that Porpora was in Rome at this time. 
Whatever happened, seems to have involved the Teatro delle Dame in Rome and its impresario, Francesco Cavanna and would have taken place during the newly established Spring season rather than the previous carnival when Porpora had been employed at the rival Teatro Capranica. The seriousness of this mishap is suggested by the fact that the delle Dame closed down in 1732, not opening its doors again until 1738 .

Failing to come through on an important opera commission at the delle Dame would have been one way of infuriating large numbers of people. There is some evidence to suggest that Porpora already failed to deliver on one, perhaps two commissions for Metastasio premieres, with the original settings of Siface in 1723 and Ezio in $1728.4^{4}$ Moreover, in 1738 Porpora did fail to fulfill an important opera commission, in celebration of King Carlo's birthday during the inaugural season of the Teatro San Carlo. To cover for Porpora's mistake, Leonardo Leo arranged Leonardo Vinci's Artaserse for the gala occasion, and the substitution not only prevented a disaster but was highly successful. 5 The scenario for failing to deliver on a opera commission thereby destroying the spring season of 1732 at the Teatro delle Dame seems plausible and fits with Porpora's reputation for "an excessively vivacious temperament ... and rather volatile." Metastasio seems to be making reference to the latter in dismissing Porpora's actions as "the caprice of an individual; and for motives so frivolous." Although a reading of the Diario of Francesco Valesio, ${ }^{7}$ and other contemporary documents, proves that the Teatro delle Dame did indeed close down in the midst of the spring season of 1732, Porpora does not appear to have any direct connection with this unexpected closure.

\section{Trouble among the Palchetti}

In March 1732 the impresarios of the delle Dame and Argentina theatres "obtained licence to have opera this coming May"; the success of the new spring season, which was first introduced the previous year, had even emboldened them to request the authorities "to allow women to perform, as was the practice during the time of Clement X." 8 These plans to expand to a second season in the spring, coming after the usual carnival season, were undertaken in spite of the lack of success of the opera the previous carnival season, with

4 Metastasio's first libretto Siface, based on Domenico David's La Forza della virtù, was done "at the request of Maestro Porpora" (Metastasio [1772] 1953, 5:177). Although written for him, Francesco Feo composed the first setting in May 1723, suggesting that for some reason Porpora was unable to fulfil the commission for the premiere, which then fell to Feo by default, with Porpora not setting the libretto to music until 1725 .

5 According to the Prince of Campoflorido, the music "con piacer grande, fu intesa da tutti, or mai son già sette anni" (Croce 1891, 338-39) and contributed to the phenominal posthumous success of Vinci's final opera.

6 "un indole soverchio vivace (come si è detto) ed assai volubile" (Villarosa 1840, 168).

7 Roman writer and diarist, the Samuel Pepys of Rome, who kept a diary from 1700 until his death in 1742 .

8 'Martedì 4: Gl'impresari de' teatri Aribert e di Torre Argentina hanno ottenuta licenza di fare i drammi per il futuro maggio ed ora supplicano per la facoltà di farvi recitare le donne, come si pratticò nel tempo di Clemente X" (Valesio 1979, 5:453). 
the impresarios unable even to win back their own expenses. The reason for this lack of success, according to Valesio, was the opening of a new opera theatre, which splintered the audience; thus the diarist blamed the scant audience at the inauguration of the new Teatro Argentina on the fact that at this time there were playing "three operas on stage, that is this one and the ones at the Alibert and Capranica, as well as another with puppets and music and three dramas in prose, at the theatres Valle, Pioli, Pallacorde di Firenze and the Pace."9 Although the impresario at the Teatro Capranica had the premieres of the two feature works of the 1732 season, Hasse's Cajo Fabricio and Porpora's Germanico in Germania, he was forced to withdraw from the spring season, "being charged with debts, being unable to pay the musicians."10

Plans for the spring season at the new Teatro Argentina also failed to materialize. On the other hand, the spring season at the delle Dame went ahead, though without the prima donne that they originally had hoped to feature, the 1588 decree of Pope Sixtus V banning women from the stage, surprisingly held firm. The spring season at the Teatro delle Dame began with the premiere of Giovanni Porta's Lucio Papirio Dittatore on 17 May, but it was marred by the outbreak of an old dispute between the ambassadors of France and the Holy Roman Empire over the palchetti or opera boxes, a dispute going back to the War of the Spanish Succession and the emperor's refusal to give up his claim to the Spanish crown. Valesio succinctly describes the problem: "Cardinal Cienfuego had two boxes in the Teatro Ariberti [delle Dame] with the arms of the Emperor, the second conceded to him as to the King of Spain, and the Ambassador of France had one." ${ }^{11}$ The problem had previously flared up at the Teatro Capranica during the carnival season of 1726 , when the French ambassador, Cardinal de Polignac, had argued that since the emperor had relinquished his rights to the Spanish crown with the recent signing of the Pragmatic Sanction, ${ }^{12}$ the imperial ambassador had no right to a second box at the delle Dame, or, if both were retained, then he should also have two boxes, one for the Kingdom of France and the other for the Kingdom of Navarre. The pro-Habsburg pontiff Benedict XIII countered Polignac, saying that since he never attended the opera, it should not matter whether he had one or two boxes (Clementi 1938, 54). In protest the ambassador, "two hours before the opera was about to begin, had his palchetto stripped of its arms and sealed."13

9 “tre drammi in scena, cioè questo, gli altri del teatro Aribert e Capranica e in oltre altro de' burattini in musica e tre in prosa de’ teatri Valle, Pioli e Pallacorda di Firenze, e la Pace” (ibid., 5:439).

10 "Giovedi 6: L'impresario del teatro Capranica si è ritirato essendo carico di debiti, non potendo essere pagati gli operarii" (ibid., 5:453).

11 "Avea nel teatro Ariberti il cardinale Cienfuego due palchetti con l'arme dell'imperatore ed il secondo eragli concesso come a re di Spagna, e l'ambasciatore di Francia uno" (ibid., 475).

12 Emperor Charles VI's edict allowing his daughter Maria Theresa to succeed him as head of the House of Habsburg, which he used as a bargaining chip in all of his political negotiations; the elaborate series of commitments to the Pragmatic Sanction fell to pieces when, upon his death in 1740, it was opposed by Prussia, initiating the War of the Austrian Succession.

13 "due ore prima che incominciasse il dramma nel teatro Capranica mandò i sguernire il palchetto togliendone l'arma e lo fece tuffare" (Valesio 1979, 4:625). The elaborateness of the festivities celebrating the birth of the dauphin during the fall of 1729, which included the premiere of Vinci and 
With the arrival in 1732 of a new French ambassador, the duc de SaintAignan, the issue again came to the fore. At the premiere of Porta's Lucio Papirio Dittatore, which began the spring season at the Teatro delle Dame, Valesio reports, "The ambassador of France did not have a centre box there, hence he took one on the side in order not to disturb the performance, having had a note from the Palace that His Holiness did not intend that in the theatre there was any prerogative or distinctions with the palchetti." 14

This appearance of acquiescence, however, was negated with the arrival of the ambassador, whose servants got into a brawl with the cook of Cardinal Acquiviva, the papal major-domo (Valesio 1979, 5:473). Although Saint Aignan dismissed his brawling servants, he found another way of getting around the "note from the palace." It was arranged that Saint Aignan was "given an adjacent box by Prince Vaini," and both palchetti were decorated with the "arms of the king," which thereby "put the crown of France in a position of equality with that of the emperor." 15 On 23 May, to celebrate the new royal palchetti in honour of the king of France and Navarre, the ambassador treated the audience to refreshments (De Angelis 1951, 42). However, his insinuating attempt to circumvent papal orders led to the closing of the theatre the following day by a decree of the governor. As Valesio dryly remarked, "For this novelty, opera has been suspended at the said theatre." 16 This severe measure may not have been aimed solely at the French ambassador, but perhaps also at the Vaini family, which included Antonio Vaini, who had handed over his box to the ambassador, and his brother-in-law Ferdinando Alessandro Minucci, the two kingpins in the theatre directorate. ${ }^{17}$

The one to suffer most from this demonstration of papal displeasure was the impresario Francesco Cavanna. Burdened with the debts from the previous carnival season, he was faced with a full company of well-rehearsed singers, musicians, and dancers with no opportunity to perform, no opportunity to refill the coffers to pay out the wages. On 9 June Valesio reports, "The musicians at the Teatro Alibert [delle Dame] are intent upon a law suit against the impresario Cavanna for payment of the opera subsequently prohibited." 18 The drama that was “prohibited” was Metastasio's latest, L'Issipile, which was published, with a dedication to the Spanish ambassador, Cardinal Bentivoglio d'Aragona, but

\footnotetext{
Metastasio's La contesa de'numi, besides celebrating the glory of the French crown, may also have been intended as a retaliation for the papal snub.

14 "L’ambasciatore di Francia non vi avea palchetto di faccia, onde ne prese uno di fianco per non distornare la recita, avendo avuto biglietto di palazzo che S. Beatitudine non intendea che ne' teatri vi fosse alcuna prerogativa o distinzione ne' palchetti" (Valesio 1979, 5:472).

15 "Ieri sera, essendosi fatto cedere dal principe Vaini il palchetto contiguo, vi fece porre l'arma del re" (ibid., 5:475); "sono della corona di Francia e ciò per metersi in possesso della uguaglianza con quelli dell'imperatore" (ibid., 5:484).

16 "Per questa novità è stato sospeso il dramma nel detto teatro" (ibid.).

17 Elisabetta Mori, "I Maccarani dal teatro di corte al teatro Alibert." In La musica a Roma attraverso le fonti d'archivio: atti del Convegno internazionale, Roma 4-7 giugno, 1992, ed. Bianca Maria Antolini, Arnaldo Morelli \& Vera Vita Spagnuolo (Lucca: Libraria Musicale Italiana, 1994), 190-91.

18 "Lunedi 9: Gli musici del teatro Aribert hanno intentata lite contro il Cavana impresario per il pagamento del dramma di poi proibito" (Valesio 1979, 5:481).
} 
with no composer named. ${ }^{19}$ Reinhard Strohm connects this aborted production to Hasse, whose setting appeared in Naples in October (Strohm 1976, II:321). Metastasio's violent diatribe against Porpora, however, indicates that this still-born Issipile was Porpora's, not Hasse's. Moreover, a reference in Cavanna's dedication of the production suggests that Metastasio attached great importance to this new setting for Rome, being the Italian premiere of his latest drama before a hometown audience: "I can even with justification promise numerous declarations of gratitude from the author ... who has exposed himself to the judgment of Rome, under the auspices of your Eminence, with this his new work." ${ }^{20}$ But why then does Metastasio blame Porpora for a mishap that was obviously the fault of the French and imperial ambassadors? Porpora must have been among the musicians, perhaps at the head of the musicians who were threatening Cavanna with legal action, since it was his opera that was "prohibited." Porpora may have already been short-changed during the previous carnival when his Germanico in Germania was the final opera to appear at the Capranica before it went under (see above). One can imagine Metastasio, who was friends with both Porpora and Cavanna, vehemently taking sides in the case, hence his reference to feeling "repugnance at being indifferent," angry with Porpora and the musicians of the delle Dame for not coming to some sort of gentlemanly arrangement that would have allowed Cavanna to recoup his losses, pay back his debts, and keep the theatre running. It was this and similar incidents that led to the establishment of the cauzione in 1754, a fixed deposit of three thousand scudi for opera and a thousand for plays to cover the salaries of the artists and artisans in the event of an untimely intervention such as the palchetti incident of 1732 and the death of the pope in $1740 .{ }^{21}$

\section{Replacing the Palchetti with the Palchettone}

What happened subsequently can be pieced together by events described by Valesio from the spring of 1732 and carnival 1733. Some type of accommodation appears to have been made between Porpora and the musicians on the one hand, and Cavanna on the other. This accommodation would have involved producing Issipile the following carnival season, with Cavanna maintaining his position at the delle Dame in anticipation that a successful season would allow him to pay back his debts. ${ }^{22}$ The first payback came in July from the French

19 L'Issipile: Dramma per musica da rappresentarsi nel Teatro delle Dame nella primavera dell'anno 1732. Dedicato all' Emo e Rmo Principe il Sig. Cardinale Cornelio Bentivoglio d'Aragona Incaricato degl'Affari di Sua Maestà Cattolica nella Corte di Roma, (Rome: Pasquino, 1732).

20 "Posso ancora giustamente promettermi numerose proteste di riconoscenza dalla gratitudine dell'Autore ... che si esponga al giudizio di Roma sotto gli auspicj dell' E.V. questa sua nuova fatica" (ibid., 5-6).

21 "Fonti per la storia del teatro romano nel Settecento conservate nell'Archivio di Stato di Roma” (Pastura Ruggiero 1989, 508).

22 A comparison of the casts of the first opera of the aborted 1732 season, Porta's Lucio Papirio Dittatore, with that of Porpora's Issipile from 1733 indicates that half of the singers from the 1732 season returned to perform in this make-up season: Domenico Annibale, Giovanni Battista Mancini and Giovanni Tedeschi (Sartori 1990, nos. 14476, 13908). Although this type of carryover of the cast may have been part of the accommodation, it was not uncommon in Italian opera during this period. 
ambassador, who "paid Cavanna in full for the two boxes that he took from him in the Teatro Aribert [delle Dame]." 23 In September Cavanna requested of the Auditor Sanctissimi that "the palchetti owners of the Alibert [delle Dame] be obliged to contribute the quota fixed by the decree of the governor of Rome, in consideration of the debts contracted [from the previous season] and of the expense sustained by the preparation of the spectacles [for the forthcoming season]." ${ }^{24}$ In the accommodation with the musicians, it would appear that since Cavanna was already in debt from the cancellation of the spring season, the governor allowed him to collect an additional fee from the palchetti owners to contribute to the preparations for the forthcoming season, anticipating the later cauzione. Probably by mid-November the Teatro delle Dame was, as Valesio reported of the Teatro Argentina, "preparing everything for the performances of the operas in the coming carnival, without knowing the manner in which to accommodate the pretensions of these ambassadors." 25

The atmosphere of uncertainty came to a head at the end of the month when the French ambassador insisted on two palchetti at the new Teatro Argentina, threatening to leave Rome if his demands were not met: "The ambassador of France has informed the [papal] Palace that if, in the theatre where the opera is to be performed, he will not have his convenience with regards to the palchetti and the coats of arms, he has orders to depart immediately from Rome; thus is lost the hopes of [having] opera in this theatre, even though [the impresario] Faliconti has already sent for the singers." 26

One encounters diplomatic disputes such as this from time to time during this period, usually over the appointment of cardinals, like that between the pope and the king of Portugal during the winter of 1727/28 when diplomatic relations were broken off and there were even rumours of war (Clementi 1938, 39). The French ambassador appears to be threatening just such a diplomatic dispute, with the suggestive "he has orders" intended to refer to Louis XV himself. The pope, wanting neither to back down nor to break off relations with the king of France, again sidestepped the issue and ordered the closure of the theatres. ${ }^{27}$ By the beginning of December Valesio reports that "the singers sent for by Faliconti to [perform] at teatro di Torre Argentina, have departed, having

23 "L'ambasciatore di Francia ha pagati intieramente al Cavana gli due palchetti da esso presi nel teatro Aribert” (Valesio 1979, 5:484).

24 Quoted in Pastura Ruggiero (1989, 515): "1732 settembre 4-supplica di Francesco Cavanna, impresario dell'Alibert, diretta all'Auditor Sanctissimi, in cui si chiede che i proprietari dei palchetti dell' Alibert siano obbligati a versare la quota stabilita per decreto del governatore di Roma, in considerazione dei debiti contratti e delle spese sostenute per l'allestimento degli spettacoli."

25 "Venerdì 14: Nel nuovo teatro de' Cesarini alla Torre Argentina si prepara il tutto per fare la recita de' drammmi nel venturo carnevale, senza sapersi il modo dell' accommodamento per le pretensioni di questi ambasciatori" (Valesio 1979, 5:533).

26 "Avendo fatto sapere a palazzo l'ambasciatore di Francia che, se nel teatro per il dramma da farsi non averà egli la sua convenienza per conto de' palchetti e delle armi, egli ha ordine di partirsi immediatamente da Roma, si è perduta la speranza delle opere in questi teatri, benché il Faliconti avesse di già fatti venire gli musici" (ibid., 5:537).

27 These orders by tragic coincidence run parallel with similar orders that were being issued in Naples at this time as a sign of public penance. On 29 November an earthquake struck Naples, the shock waves being felt throughout Rome "per lo spazio di un Credo" (ibid., 5:538; Croce 1891, 298). 
received orders not to do the opera." ${ }^{28}$ By the end of the month he reports that "Cavanna, the impresario at the Teatro Alibert [delle Dame] has withdrawn because of his debts." 29

In a somewhat extended entry in the New Year, Valesio provides the background to these two events that signalled the closure of the two opera theatres in Rome prior to the carnival season of 1733: "Because of the noted difficulty set in motion by the French ambassador with the palchetti with the two coats of arms described previously, it was believed that the comedies [i.e., operas] would not be performed: in the end permission was given, but [only] by demolishing the palchetti and making there a single palchettone in front for the ladies."30

In the eleventh hour, the pope appears to have reversed his decision, giving permission for the opera but with this most unusual proviso. Considering that the development of public opera in Italy was based on the sale of the palchetti that were leased as virtual extensions of the family palazzo, the wholesale destruction of the palchetti seems a rather extreme measure. Valesio describes how when this innovation was first proposed to the French ambassador, he replied that he should have a place in the palchettone with the ladies-his suggestion satirized as letting "the rooster in the henhouse" in an anonymous pasquinade. ${ }^{31}$ According to Clementi's study of the Roman carnival, this proviso also interfered with the venerable Roman tradition of the cicisbei. This was the age of the cicisbeo-the young lover of a married woman, the age when Roman marriage contracts supposedly contained a clause specifying that "the husband will never accompany the wife outside the house on walks, to the theatre and on visits" and that stylish Ladies should have at least three cicisbei (Clementi 1938, 55-56). Several important artists established their careers as cicisbei, such as Metastasio and Rousseau..$^{32}$ The idea that the ladies would be cloistered in a palchettone or balcony was unthinkable, and by the middle of January Valesio reported yet another change in the seating arrangements for the 1733 season that allowed for the "mingling of men and women ... within a single file of open palchetti, without partitions, having the rest of the walls ornamented with

28 "Sabato 6: Oggi partirono gli musici fatti venire da Faliconti per il teatro di Torre Argentina, essendo venuto l'ordine di non farsi le comedie" (Valesio 1979, 5:543).

29 "Il Cavana, impresario del teatro d'Aribert, si è ritirato per gli debiti" (ibid., 5:551).

30 "Sabato 10: Per la nota difficoltà posta in campo dall'ambasciatore di Francia de' palchetti con le due armi, come già si scrisse, si credeva che non si sarebbono fatte le comedie: alla fine ne fu data la licenza, ma con demolire i palchetti e farvi un solo palchettone in faccia per le donne" (Valesio 1979, 5:557).

31 De Angelis 1951, 42. The pasquinades were anonymous satiric verses that were attached to the statue of the commedia dell'arte character Pasquino, hence the name.

32 Although the "special relationship" between Marianna Benti Bulgarelli and Metastasio was rather different from that between Louise Éléonore de Warens and Rousseau because of their operatic collaborations, the patron-protégé relationships between older women and younger men clearly included additional amorous aspects, as can be gleaned from their correspondence and other sources. For example, the ménage à trois between Metastasio, La Bulgarelli, and Signor Bugarelli provides the subtext of the poet's first two libretti, Angelica and Gli Orti Esperidi. 
damask and other adornments." 33 If the near-cancellation of the theatre season was a means of avoiding further confrontation with the French ambassador, the subsequent destruction of the palchetti may not have been only a peculiar way around this problem, but also may have been intended to discourage some of the more flagrant abuses of cicisbeismo.

\section{The Premiere of Porpora's Issipile}

Where does Porpora's Issipile fit into all this? With the order to destroy the palchetti and rebuild the auditoriums around the new palchettone, the directors of both the Argentina and delle Dame theatres appear to have been unwilling to embark on such a destructive undertaking that seemed to strike at the very core of the theatrical tradition of Italian opera. They apparently decided to wait it out, either for the order to be rescinded or the pope to die, Clement XII being blind and bedridden with gout at the time. With the cancellation of the season, Cavanna, unable to recoup his loses from the previous year in a new season, was compelled to withdraw-presumably a polite phrase for bankruptcy. In the new year "an inventory of the wardrobe and sets at the Teatro Alibert [delle Dame] was made at the request of Francesco Cavanna," as had been done when the Royal Academy of Music in London closed in 1728.34 While Faliconti had sent home the singers and musicians engaged by the Teatro Argentina, it would appear that those engaged by the delle Dame remained in Rome.

With the eleventh-hour decision to proceed with the season, arrangements were made, perhaps by Cavanna himself, to have Issipile produced at another theatre that was willing to undergo this radical accommodation: "Today the governor went in person to see the theatre, which they have prepared, namely, that of the Pioli in the Palazzo Rucellai on the Corso, where they have demolished all of the palchetti as well as in that of the Granari behind S. Agnese and the newly built Tor di Nona." 35

Therefore at three of the small theatres the palchetti were replaced with the palchettone: the Pioli, the Granari, and the Tordinona. The new Teatro Tordinona opened its doors with a commedia in prosa the day after Valesio's entry. It was not until the end of the month, on 24 January 1733, that Teatro Pioli, one of the theatres for spoken comedy, was ready for the premiere of Porpora's opera Issipile. According to Valesio, the premiere of Issipile was not a great success, as a result of the new seating arrangements and the expensive ticket prices: "In the evening the dramma in musica was performed for the first time at the Teatro de' Pioli in the Corso near the palazzo Ruspoli, with a sparse audience since they were at other venues; the nobility did not come because they did not

33 "Si è dato principio al frequentare anche da donne meschiate con uomini e si fanno le comedie in prosa con una sola fila di palchetti aperti e senza tramezzi, essendo il resto delle mura ornato di damaschi ed altri apparati" (Valesio 1979, 5:559).

34 Quoted in Pastura Ruggiero 1989, 515: “1733 Marzo 20-inventario del guardaroba e degli stigli del Teatro Alibert fatto ad istanza di Francesco Cavanna.”

35 "Oggi il governatore in persona andò a vedere i teatri che si preparano, cioè quello del Pioli nel palazzo Rucellai al Corso, dove erano stati demoliti tutti gli palchetti, siccome in quello de’ Granari dietro S. Agnese e il fatto nuovo a Tor di Nona" (Valesio 1979, 5:557). 
want to mingle with the other [classes], the palchetti no longer being there. The admission, which in the other places is two giuli, in this one is three giuli in the pit, four in the more elevated circle under the palchettone, and five in the actual palchettone." 36

In spite of the inauspicious start and the outbreak of a flu epidemic, the opera continued onstage until the end of carnival. Some of the nobility found ways of accommodating themselves to the new seating arrangements, by individual princes taking over the entire palchettone for the evening, as the nipote Prince Corsini did on 28 January: "In the previous evening, Prince Corsini with all his family, having taken a complete palchettone at the opera at the Teatro Pioli, invited there many ladies to whom he gave lavish refreshments." 37 A balcony full of drinking ladies probably attracted some eager young men in the pit. On 11 February "il re d'Inghilterra" (the Old Pretender) took over the palchettone and, "having dined there, he had magnificent refreshments distributed to those in the pit wherein many were nobles." 38

And what was Porpora doing this season besides supervising the premiere of an opera he had written the previous spring? On 19 November Valesio describes the arrival in Rome of the duke of Monte Leone, "the very same evening that the said cardinal was having performed the cantata in honour of the empress's nameday with lavish refreshments."39 The libretto of this cantata states that the composer was Porpora and the patron who commissioned the work was Cardinal Cienfuego, the imperial ambassador, one of the culprits in the palchetti wars. ${ }^{40} \mathrm{~A}$ month later Valesio reports of another gala cantata performance, the final rehearsal for the pope's annual Christmas cantata: "In the previous evening, Cardinal Acquaviva, who has given up the office of papal major-domo, has had the rehearsal of the cantata, to be performed on Christmas Night in the royal hall of Monte Cavallo, and in the adjoining ducal hall there were invited

36 “... la sera si fece per la prima volta nel teatro de' Pioli al Corso incontro al palazzo Ruspoli il dramma in musica con non molto concorso, siccome ne gli altri luoghi, non volendovi andare la nobiltà per non accommunarsi con altri, non essendovi più gli palchetti. Il pagamento, dove ne gli altri luoghi è di 2 giuli, in questo nella platea è di 3 giuli, 4 nel giro alquanto elevato sotto al pachettone e di 5 sul medesimo palchettone" (ibid., 5:560).

37 "Giovedì 29: Nella sera precedente il principe Corsini con tutta la famiglia, avendo preso un palchettone intiero al dramma del teatro Pioli, vi invitò molte dame, alle quali diede un lauto rinfresco" (ibid., 5:561).

38 "Questa sera, essendo andato il re d'Inghilterra ad udire il dramma nel teatro Pioli, avendo ivi cenato, fece distribuire magnifici rinfreschi a quelli che erano nella platea, nella quale vi era molta nobiltà" (ibid., 5:566).

39 "appunto il detto cardinale in questa sera facea la cantata per il nome della imperatrice con un sontuoso rinfresco" (ibid., 5:535) .

40 Componimento drammatico: da cantarsi nel giorno del glorioso nome della sacra cesarea cattolica real maestà della imperatrice regnante Elisabetta Cristina per comandamento dell'em.mo cardinale Alvaro Cienfuegos ministro plenipotenziario presso la Santa Sede Apostolica. Di O.L.P.A. (=Lalli, Domenico?) Musica di Niccolò Porpora maestro delle figlie del coro del pio Ospedale degli'Incurabili in Venezia (Roma, Stamp. del Kormarek, 1732); copies of the libretto in I-Mb - MAC - Rli - Vc,Torrefranca (Sartori 1990, no. 6010). 
to hear it twelve cardinals in corto abito, a quantity of prelates and what is more, about twenty women, to whom were given formal refreshments." ${ }^{31}$

The papal Christmas cantata, which had a substantial tradition going back at least to the turn of the century, was performed at the Papal Palace on Christmas Eve between First Vespers and Matins in conjunction with a lavish banquet that featured elaborate sculpted sugar/marzipan trionfi (Marx 1992, 180). Although these cantatas were usually commissioned from the maestri of the major churches in Rome, occasionally they were commissioned from outside composers, the published libretto giving Porpora's current position as "maestro delle figlie del coro del Pio Ospedale degl'Incurabili in Venezia" from which he was on leave..$^{2}$ In contrast to the serenata for which Porpora's score has been lost, a score of his Christmas Cantata survives in the Library of the Conservatory in Rome. ${ }^{43}$ As for the music of Issipile, it survives incomplete; a manuscript of act 1 is at Montecassino, with another four arias at the Royal College of Music in London, and three arias in the Bodleian Library in Oxford (Strohm 1976, II:208).

\section{The War of The Polish Succession}

The political background behind the palchetti incident is not easy to determine. The obvious thing would be to connect it with the War of the Polish Succession (1733-38), which dominated European politics during the mid-173os and saw France and Austria fight it out, not in Poland but primarily in Italy. However, the war began with the deposition of Stanislas Lesczynski, father-in-law of both Louis XV and the Old Pretender, and the subsequent declaration of war by France against the empire in October 1733, was almost a year and a half after the incident began. To say that the incident prefigured the breakdown of relations between France and Austria and the subsequent war would be a distortion of the complex political situation in Europe prior to the war. During the period between the end of the War of the Spanish Succession and the beginning of the War of the Polish Succession, war could have broken out at any time, involving various combinations of nations. ${ }^{44}$ In the spring of 1732 it was more likely that England or Austria and Spain, which had been sporadically in conflict throughout these years, would go to war again. It is not

41 "Nella sera precedente il cardinale Acquaviva, che dee lasciare l'offizio di maggiordomo pontificio, fece fare la prova della cantata da recitarsi nella notte di Natale nella sala regia in Monte Cavallo, e nella prossima sala ducale vi erano ad udirla invitati dodici cardinali in abito corto, quantità di prelati e, quello che è più, circa venti dame, a' quali fu dato un solennissimo rinfresco" (Valesio 1979, 5:548).

42 Cantata: da recitarsi nel Palazzo Apostolico la notte del SS.mo Natale l'anno 1732. Musica del signor Niccolò Porpora, maestro delle figlie del coro del Pio Ospedale degl'Incurabili in Venezia (Roma, Stamperia della Rev. Camera Apoltolica); copies in I-R,Caetani - R,Istit.Germanico - Rli DMbs (Sartori 1990, no. 4680).

43 Strohm, Italienische Opernarien des frühen Settecento, 208; this oratorio has been been recorded in the mid-199os and was the first large-scale work by Porpora to make it to disc (Bongiovanni GB 218182-2).

44 Penfield Roberts, The Quest for Security: 1715-1740, The Rise of Modern Europe, ed. William L. Langer (New York: Harper \& Row, 1947), see Chapter 1 "Stabilization in the West" \& Chapter 9 "The Uneasy Balance". 
clear why Pope Clement should have consistently favoured the imperial ambassador throughout the palchetti conflict but, with the outbreak of the War of the Polish Succession, he shifted his support from one candidate and then the other (Kelly 1986, 296). On the whole, the papacy of Clement XII was characterized by its inept, erratic, and indecisive policies with regards to the great powers, being caught between the Bourbons and Habsburgs, trying to assert prerogatives that were pathetically out of date.

In sorting out the bewildering web of alliances and treaties during the eighteenth century, particularly between the Wars of the Spanish and Polish Successions, one is struck by that amazing mirroring between life and art that occurs from time to time throughout European history: the intrigues, negotiations, and conspiracies that took place onstage in a Metastasian dramma per musica such as Issipile were also taking place in the palchetti, particularly in theatres of Venice and Rome that were frequented by foreign princes, diplomats, and ambassadors involved in these momentous events. These alliances and treaties, based on a strange mixture of modern economic and antique dynastic considerations, often produced capricious twists and turns as strange as the opera plots themselves. The eventual outcome of the War of Polish Succession has a definite "feel" of a Metastasian dénouement, with couples being united and kingdoms being assigned by the magnanimous victors. By the Third Treaty of Vienna signed in October 1735, the elector of Saxony, August III, the imperial candidate, succeeded his father as king of Poland, while Stanislaus Leszczynski, the French candidate, renounced his claim to the Polish throne, albeit retaining the title of king and receiving the Duchies of Lorraine and Bar, which would be inherited by his daughter Marie, wife of Louis XV, France thereby finally obtaining the province of Lorraine which it had fought for over the centuries; François, duke of Lorraine, was married to Maria Theresia and given Tuscany. Besides compensating François for the loss of Lorraine, Tuscany combined with the neighbouring Duchies of Parma and Piacenza compensated Austria for the loss of Naples, which was given to Don Carlos, who a few years later married the daughter of the new Polish king, becoming the founder of a new Neapolitan dynasty (Roberts 1947, 254-55).

One might even be tempted to detect the influence of Metastasio in some of these diplomatic manoeuvres through the frequent attendance at the opera by many of Europe's rulers and diplomats, with the notion that there was no political situation too difficult that a few strategic dynastic marriages could not sort out. In fact the outcome of the story of Metastasio's Issipile just so happens to have an uncanny resemblance to the Third Treaty of Vienna, which ended the War of the Polish Succession. The story is based on the marriage of Giasone and Issipile, with the long-suffering heroine triumphant in the end, resolving a host of problems and winning back her man. The story was probably chosen as a tribute to the Archduchess Maria Theresa, heiress to the Habsburg succession and her new husband François of Lorraine, with the evil widow Eurinome and her son Learco, the unsuccessful suitor to Issipile, representing the archschemer Elizabeth Farnase, widow of the duke of Parma and queen of Spain, and her son Don Carlo, who had previously been proposed as a husband for 
Maria Theresa in the First Treaty of Vienna in 1725. It must be admitted that the political allegory is not perfect, these political allegories seldom are; thus, the father of Issipile, the old roué Toante, would be Emperor Charles, Metastasio's boss, who was one of the few reigning monarchs who did not keep mistresses and remained faithful to his wife..

\section{The Teatro Tordinona and the Gradual Reopening of THe Delle Dame}

The following year, 1734, the Teatro Pioli/Rucellai returned to being a venue for the spoken theatre as the new Teatro Tordinona, built "on the site of the celebrated theatre that was razed to the ground by Innocent XII," 45 was refitted to accommodate opera. The renovation of the Tordinona, which, according to Valesio, had the official support of the pope himself via a loan to the impresario, strangely enough involved the building of ornate palchetti: "Having obtained licence to renovate the Teatro di Torre di Nona in order to perform an opera in musica for the next carnival, His Holiness has given Faliconti a loan to this purpose of 2,000 scudi with a pledge that ... he will make there three orders of palchetti to lease on each evening without carrying any arms; today they have set to work more than two hundred men."46

Giuseppe Polvini Faliconti, the former impresario at the Capranica and the Argentina theatres, whom Metastasio nicknamed "the green grocer of Parnassus," managed to get around the palchetti ban by selling them for each performance and prohibiting coats of arms. The palchetti were chosen by drawing lots-undoubtedly the influence of the lottery, which had been re-introduced into Rome by Clement XII (Clementi 1938, 52-53). On the opening night the French ambassador just happened to draw one of the best centre palchetti. In spite of the scarcity of opera in Rome during these years, Valesio again complains that "there was not a great crowd/ non vi fu gran concorso" (Valesio 1979, 5:667).

During this season a second opera theatre opened in the "sala del palazzo de'Cesarini alle Stimmate" by the "comedie de'quaranta," so called because of its board of forty directors. As in 1733, the quaranta asked permission to have women appear onstage, and this time permission was granted: their first production, the dramma pastorale La Flora by Costanzi, Corticelli, and Vasnier featured "due donne cantarine" and was promoted by a quantity of "bolettini gratis" (Valesio 1979, 5:668). This long-awaited appearance of women onstage could not have made a favourable impression on the audience or the authorities, and in the future the ban of Sixtus $\mathrm{V}$ would continue to be maintained. Not satisfied by these novelties, the Quaranta also opened "a certain game

45 "Il fatto nuovo a Tor di Nona, dove già fu il celebre teatro fatto atterrare da Innocenzo XII" (Valesio 1979, 5:557).

46 "Giovedì 21: Avendo il Faliconti ottenuta licenza di rifabricare il teatro di Torre di Nona per recitarvi una opera in musica nel prossimo carnevale, dando S. Beatitudine in prestito a tale effetto scudi 2.000 con patto che ... vi si faranno tre ordini di palchetti da affittarsi in ciascheduna sera senza porvi alcuna arma ed oggi vi sono andati a lavorare più di duecento uomini” (ibid., 661). 
of roulette, a species of knavery that in other times was prohibited, but now makes a profit for the master of the house of Corsini [the pope's nephew]."47

During the next three years, though operas were produced in several different theatres, the Teatro Tordinona had become the principal opera theatre in the papal city. It was there that Pergolesi's music was introduced to Rome: first with La serva Padrona, which appeared between the acts of Ciompi's Demofoonte during carnival 1735, followed by the premiere of Olympiade the following spring. Although Valesio does not mention the stormy reception in which Pergolesi was supposedly hit in the head with an orange, he does mention a fight between two cicisbei over a women, which may have been the incident around which the anecdote originated (Valesio 1979, 5:797).

The principal rival of the Tordinona during these years was the Teatro di Valle. In 1735 the owners of the Capranica, Camilio Capranica and Domenico Valle, obtained a licence allowing them to "perform there works in music or in prose." 48 As well in 1737 the Teatro Argentina reopened to produce "comedy in prose, burlettas, intermezzi in musica, but not for the use of opera in musica."49 The Argentina probably got around the palchetti ban in the same way as the Tordinona, by drawing lots-the palchetti clearly visible in the famous painting by Pannini. Although the Valle was licensed to produce opere in musica while the Argentina was not, both theatres began to produce burletti and intermezzi, thereby establishing regular venues for comic opera in Rome, allowing the Tordinona to concentrate its attention on the traditional dramma per musica.

The delle Dame finally reopened its doors for carnival 1738 with a production of Achille in Sciro..$^{\circ}$ The performance notice, which alludes to the dispute between French and imperial ambassadors, also mentions that this dispute had finally been resolved: "went on stage for the first time the drama entitled Achille in Sciro, in that theatre which at the beginning of this pontificate, they did not perform operas because of the disagreements that took place among the royal ministers concerning the palchetti; now all these have been resolved and they have taken up again to perform comedie in musica [i.e., operas] as was formerly the practice." 51

47 "Lunedi 25: Gli quaranta della comedia alli Cesarini hanno avuta la licenza di farla e si è aperto un certo gioco di roullet, che è una specie di biribisse, che altre volte fu proibito ed ora si fa a conto a guadagno del maestro di casa de' Corsini” (ibid., 662).

48 Quoted in Pastura Ruggiero 1989, 555: "rinnovo del contratto di affitto del teatro tra Camillo Capranica e Domenico Valle, per farvi recitare opere in musica o in prosa e per il canone di sc. 400 annui."

49 "ad uso di far comedie in prosa, burlette, intermezzi in musica, ma non mai ad uso di opere in musica” (ibid., 518).

50 Although no composer is given, this is probably a revival of Domenico Sarro's setting of Achille in Sciro, which had received its gala première two months earlier for the opening of the new Teatro San Carlo. Maione and Seller 2005, 1:19-21.

51 Quoted in Rava 1953, 72: "A di 7 detto. Martedì sera nel teatro Aliberti a Piazza di Spagna detto il teatro delle Dame posto agli Orti di Napoli, andò in scena per la prima volta il dramma intitolato Achille in Sciro, nel quale teatro sino dal principio di questo Pontificato non si erano fatte comedie per le differenze che passavano tra Ministri delle Corone intorno a Palchetti, ora si sono levate tutte, e così si è ripigliato a capo a farvi comedie in musica come era il consueto." 
There must have been some type of connection between the Teatro Tordinona and the Delle Dame; during the refurbishing of the Tordinona, Valesio mentions that "all the money paid out of the [Apostolic] Chamber passed through the hands of the financier Minucci," who was one of the principal directors of the delle Dame..$^{2}$ Moreover, with the reopening of the Delle Dame in 1738 , the Tordinona closed its doors, giving the impression that it had served its purpose, which apparently was to allow the Vaini family to continue producing opera during this strained period without having to destroy the celebrated five tiers of palchetti for which the delle Dame was renowned. Although Clementi assumed that the palchetti at the delle Dame were destroyed, it appears that instead the directors transferred their activities to other theatres, first to the Teatro Pioli Rucellai, which underwent this destructive renovation, and then to the Teatro Tordinona, where they used the lottery to get around the restriction. With the resolution of the conflict, it would appear they simply abandoned the Tordinona and reopened the delle Dame.

\section{Porpora's Return to Rome}

Although the five tiers of palchetti remained, things must have seemed rather different to Porpora when his Carlo il Calvo was produced at the delle Dame during the spring of 1738 . Not only had comic opera been established on a regular basis, but a new generation of Neapolitan-trained composers had come of age: Latilla with Temistocle at the Tordinona in 1737, Logroscino with Quinto Fabio at the delle Dame in 1738, Terradellas with Astarto at the delle Dame in 1739, and Jommelli with Ricermero at the Argentina in 1740-composers associated with the mid-century. Since the premiere of Issipile, Porpora had spent the past three seasons in London as principal composer for the Opera of the Nobility. In his celebrated rivalry with Handel, Porpora was most definitely the loser, though he probably salvaged some of his reputation with the publication of the Cantatas op. 1 on texts by Metastasio, which came to be regarded as "his Master-Pieces" (Hawkins [1776] 1963, 2:877). Although this set of cantatas could represent a reconciliation between the composer and poet after their falling out over Issipile, more than likely the texts were written during their early collaborations in Naples, when the poet was still content to serve as anonymous collaborator to his maestro. This, in turn, would explain why they were published without the poet's name and why they were, like Siface, only casually acknowledged by Metastasio at the end of his career (Metastasio [1772] 1953, 5:171). Had the texts been newly written for Porpora by the imperial poet laureate, this surely would have been mentioned on the title page. As for Porpora's claim that the cantatas were newly composed, this could be pure sales talk or would apply to cantatas that were composed specifically to make up the batch of twelve for publication - as with Siface, Porpora took his time getting around to finishing the cantatas as a set.

52 "tutto il denaro lo dà fuori la Camera passando per le mani del depositario Minucci" (Valesio 1979, 5:661). 
Although returning to Italy saw a return to the patterns of the past, with opera commissions in Venice, Rome, and Naples, he was no longer the avantgardiste he once was. In the ultra fashion-conscious Italy of the 1740s, Porpora's music was coming to be regarded as somewhat old-fashioned. In 1740/41 Porpora's regular production of one or two operas a year came to an end. And just as his former rival Handel was retiring from opera, forging a new career for himself as the composer of English oratorio and music drama, Porpora began to make a new career as composer of sacred music for the conservatories in Venice and Naples. What was too old-fashioned for the theatre could become profound in a sacred context.

Many years later in Vienna, transgressing his own advice, Metastasio would again be disappointed by Porpora. In the winter of 1753 Metastasio was writing a new azione teatrale to be produced by his friend, the great castrasto Farinelli in Madrid. The "gemelli" decided that the new work, L'isola diabitata, would be set to music by their old master Porpora, in spite of Metastasio's reservations about "Porpora's laziness, the uncertainty that after so long an idleness, he would accommodate your taste." 53 However, when the libretto was ready to be set to music, "Porpora, who in spite of his years has the health of a Jesuit, just when I had need of him, came down with a considerable catarrh, with persistent deterioration, and (what is worse) with a violent apprehension of death, that not only robbed him of his faculties, but threatened to delay his recovery for a long time." 54 The libretto was given to the imperial Hofkapellmeister Giuseppe Bono, and Porpora lost out on what could have been the most important work of his old age. Instances such as these contributed to Porpora gaining a reputation for being "rather volatile," though certainly not the scoundrel that Metastasio's remarks from the spring of 1732 made him out to be (Villarosa $1840,168)$. Moreover it was Metastasio who was probably responsible for introducing Porpora to the young musician who would become his most famous pupil. Joseph Haydn, who became Porpora's valet, student, and keyboard accompanist during these years, later stated that he learned "the true fundamentals of composition from the celebrated Herr Porpora" (Haydn [1776] 1959, 19).

\section{REFERENCES}

Brunelli, Bruno, ed. 1953. Pietro Metastasio, Tutte le Opere. Milan: Arnoldo Mondadori.

Burney, Charles. 1796. Memoirs of the Life and Writings of the Abate Metastasio: In Which Are Incorporated, Translations of his Principal Letters. London: C.G. \& J. Robinson.

53 "la pigrizia di Porpora, l'incertezza che dopo un così lungo ozio egli incontri il vostro genio" (Metastasio [1753] 1953, 3:797); Metastasio and Farinelli were known as the "gemelli" because they both made their debut in Porpora's Angelica in Naples in October of 1720; there was probably sentimental and symbolic intent in bringing together these three artists at the end of their career to parallel their beginnings.

54 "Porpora, che a dispetto degli anni ha una salute da gesuita, appunto quando si avea bisogno di lui si trovò alle mani con un considerabile catarro, con una ostinata alterazione, e (quel ch'è peggio) con una apprension violenta di morire, che non solo gli toglieva allora la facoltà di applicare, ma minacciava di non restituirgliela per lungo tempo" (ibid., 3:80o). 
Clementi, Filippo. 1938. Il carnevale romano nelle cronache contemporanee: sec. XVIII-XIX. Città di Castello: Unione arti grafiche.

Croce, Benedetto. 1891. I teatri di Napoli: secolo XV-XVIII. Naples: Luigi Pierro. De Angelis, Alberto. 1951. Il teatro Alibert o delle dame: 1717-1863. Tivoli: Arti Grafiche A. Chicca.

Haydn, Joseph. (1776) 1959. "Autobiographical Sketch: To Mademoiselle Leonore." In The Collected Correspondence and London Notebooks of Joseph Haydn, ed. H.C. Robbins Landon, 18-21. London: Barrie and Rockliff.

Hawkins, Sir John. (1776). 1963. A General History of the Science and Practice of Music. Reprint, New York: Dover.

Kelly, J.N.D. 1986. The Oxford Dictionary of Popes. Oxford: Oxford University Press.

Maione, Paologiovanni, and Francsca Seller. 2005. Teatro di San Carlo di Napoli: Cronologia degli spettacoli. Vol. 1, 1737-1799. Naples: Altrastampa Edizioni.

Marx, Hans Joachim. 1992. "Weihnachtsoratorien aus der ersten Hälfte des 18. Jahrhunderts." In Archiv für Musikwissenschaft 49:163-99.

Mori, Elisabetta. 1994. "I Maccarani dal teatro di corte al teatro Alibert." In La musica a Roma attraverso le fonti d'archivio: atti del Convegno internazionale, Roma 4-7 giugno, 1992, ed. Bianca Maria Antolini, Arnaldo Morelli, and Vera Vita Spagnuolo, 183-203. Lucca: Libraria Musicale Italiana.

Metastasio, Pietro. 1732. L'Issipile: Dramma per musica da rappresentarsi nel Teatro delle Dame nella primavera dell'anno 1732. Dedicato all'Emo e Rmo Principe il Sig. Cardinale Cornelio Bentivoglio d'Aragona Incaricato degl'Affari di Sua Maestà Cattolica nella Corte di Roma. Rome: Pasquino.

__. 1953. Tutte le Opere, ed. Bruno Brunelli. Milan: Arnoldo Mondadori.

Pastura Ruggiero, Maria Grazia. 1989. "Fonti per la storia del teatro romano nel Settecento conservate nell'Archivio di Stato di Roma." In Il teatro a Roma nel Settecento, ed. Gianni Eugenio Viola, 505-56. Rome: Istituto della Enciclopedia Italiana.

Rava, Arnaldo. 1953. I teatri di Roma. Rome: Fratelli Palombi.

Roberts, Penfield. 1947. The Quest for Security: 1715-1740, The Rise of Modern Europe, ed. William L. Langer (New York: Harper \& Row).

Sartori, Claudio. 1990. I libretti italiani a stampa dalle origini al 180o: catalogo analitico con 16 indici. Cuneo: Bertola e Locatelli Editori.

Strohm, Reinhard. 1976. Italienische Opernarien des frühen Settecento (17201730). In Analecta Musicologica. Vol. 16/I and II. Cologne: Arno Volk.

Valesio, Francesco. 1979. Diario di Roma, ed. Gaetana Scano and Giuseppe Graglia. Milan: Longanesi.

Villarosa, Marchese di. 1840. Memorie dei compositori di musica del Regno di Napoli. Naples: Stamperia Reale. 


\begin{abstract}
"Where Porpora is concerned, misfortune is bound to ensue. Beware, in faith, of having anything to do with his company." Metastasio's damning indictment of Nicola Porpora in a letter published in his Opere (the offending passage omitted from Charles Burney's English translation) is put into the context of the "Palchetti Wars" in Rome in $1732 / 33$ and a court case against the impresario Francesco Cavanna of the Teatro della Dame. The court case was filed by a group of musicians, presumably led by Porpora, after the cancellation of the premiere of his Issipile during the spring of 1732 as a result of the closing of the theatres by the pope due to the controversy between the ambassadors of France and Austria over their boxes (palchetti) at the opera. In the court case between two of his old friends, Metastasio took the cause of the impresario over the composer because the case resulted in the bankruptcy of Cavanna and the closure of the della Dame. Although arrangements were made for the premiere of Porpora's Issipile the following year at an alternate venue, the Teatro Pioli-which got around the theatrical ban by replacing its palchetti with a large balcony or palchettone, the della Dame, preserving its celebrated five tiers of palchetti-remained closed until 1738. This was probably part of the strategy of the directors of the delle Dame in dealing with the twists and turns of the palchetti controversy.
\end{abstract}

\title{
RÉSUMÉ
}

«Là où est impliqué Porpora, le malheur suit. Méfiez-vous, en vérité, d'avoir affaire avec lui ». Les accusations accablantes que porte Métastase à l'endroit de Nicola Porpora dans une lettre incluse dans son Opere (le passage ayant été omis par Charles Burney dans sa traduction anglaise) peuvent être mises en lien avec la "Guerre des loges" se déroulant à Rome en $1732-33$ et un procès contre l'imprésario Francesco Cavanna du Teatro della Dame. La cause avait été présentée par un groupe de musiciens, sans doute mené par Porpara, suite à l'annulation, au printemps 1732, de la première de l'opéra de ce dernier, Issipile. Cette annulation était due à la fermeture des théâtres par le pape en raison du conflit entre les ambassadeurs de France et d'Autriche au sujet de leur loge à l'Opéra. En effet, dans cette polémique, Métastase prit le parti de l'imprésario, au dépend du compositeur, parce qu'elle avait entraîné la faillite de Cavanna et la fermeture du Treatro della Dame. Bien qu'une entente ait été conclue pour que la première de l'Issipile de Porpora ait lieu l'année suivante dans un théâtre différent, le Teatro Pioli qui avait transformé ses loges en un grand balcon — le Teatro della Dame, lui, a gardé ses cinq niveaux de loges et est demeuré fermé jusqu'en 1738. Cette décision du Teatro della Dame peut être considérée comme une stratégie délibérée face à la controverse de la "Guerre des loges". 